\title{
The Effect of Postnatal Development on the Adherence of Nonfimbriated and Fimbriated Salmonella typhimurium to Isolated Small Intestinal Enterocytes
}

\author{
ALI MOUSTAFA ABD EL MONEM, ${ }^{1}$ MOHAMMED SAAD, ${ }^{2}$ BO L. LINDQUIST, PING- \\ CHEUNG LEE, RODNEY ABUD ${ }^{3}$ JOSEPH M. MERRICK, AND EMANUEL LEBENTHAL \\ International Institute for Infant Nutrition and Gastrointestinal Disease, Children's Hospital, [A. M. A. E. M., M. \\ S., B. L. L., P-C. L., R. A., E. L.J New York 14222 and Department of Microbiology, State University of New \\ York at Buffalo [B. L. L., J. M. M.], Buffalo, New York
}

\begin{abstract}
The adherence of radiolabeled fimbriated (S $7471 \varphi F)$ and nonfimbriated (S 7471 N) Salmonella typhimurium to small intestinal rat enterocytes was examined during postnatal development. The fimbriated strain invariably adhered in higher numbers than the nonfimbriated strain during all periods of development. The capability of enterocytes to bind Salmonella increased significantly during postnatal development and reached adult levels at weaning time ( 21 days of age). Bacterial adherence to enterocytes was similar if the cells were isolated from the proximal or the distal small intestine. Early weaning of pups did not affect the capability of enterocytes to bind Salmonella. Pretreatment of isolated enterocytes from adult animals with rat's milk before exposure to Salmonella had no effect on the level of bacteria that adhered per enterocyte. Conversely, pretreatment of Salmonella with rats' milk before binding to enterocytes from adult animals also did not alter the level of bacteria adhered per enterocyte. These results suggest an age-dependent, postnatal development of available receptors for $S$. typhimurium on rat enterocytes. The acquisition of these receptors is not affected by mother's milk and is unaltered by early weaning. (Pediatr Res 24: 508-511, 1988)
\end{abstract}

Infectious and noninfectious infantile diarrhea are leading causes of childhood morbidity and mortality especially in communities where malnutrition and deficient hygiene prevail $(1,2)$. Studies in 15 developed and lesser developed countries indicated that Salmonella was the etiologic agent of acute diarrhea in children in $0.9-18 \%$ of the cases and that Salmonella typhimurium was the strain most frequently isolated (2-4). The highest incidence of salmonellosis occurs in the second half of the first year of life $(2,4)$, much more frequently in weaning and formula-

Received July 17, 1987; accepted June 24, 1988

Correspondence and reprint requests Emanuel Lebenthal, M.D. The International Institute for Infant Nutrition and Gastrointestinal Disease, Children's Hospital, 219 Bryant Street, Buffalo, NY 14222

A. M. A. E. M. and M. S. supported by United States Agency for International Development for fellowships at the International Institute for Infant Nutrition and Gastrointestinal Disease, Buffalo, NY. B. L. L. supported by the Foundation Samariten Sweden and the Swedish Medical Research Council. R. A. supported by the National Council for Research and Technological Development, Brazil, CNP $_{\mathbf{a}}$

${ }_{1}^{1}$ Present address Department of Pediatrics, University of Cairo, Cairo, Egypt.

${ }^{2}$ Department of Pediatrics, Al-Azhar University, Cairo, Egypt.

${ }^{3}$ Department of Pediatrics, Catholic University of Sao Paulo (PUC-SP), Sao Paulo, Brazil. fed infants than in breast-fed infants $(1,5)$. This has been clearly shown to be an effect of mother's milk $(1,5)$ but it has also been suggested that variation in intestinal mucosal receptor activity for enteropathogens could be an important contributing factor to the age-related clinical pattern of intestinal infections (6).

Adherence of bacteria to epithelial cells is generally recognized as a prerequisite for colonization as well as for the pathogenesis of enteric infections (7-10). Binding of bacteria to intestinal epithelium is considered to require specific interaction between bacteria and host cell surfaces (11). However, little is known about the molecular characteristics of the receptors for enteric bacteria. The intestinal epithelium undergoes major structural and functional transformations in their surface proteins and carbohydrates during postnatal development (12). It is conceivable that surface receptors for bacteria on the enterocytes also undergo developmental changes. Such transformations would have important effects on colonization by indigenous microflora as well as for the clinical pattern of intestinal infections in the neonatal period.

As yet, there are no ontogenic studies on intestinal adherence of Salmonella typhimurium. A few studies have been reported on the postnatal development of adherence of Escherichia coli and Shigella flexneri to intestinal mucosal cells in animals (6, 13-15). In the present study, we investigated the effect of postnatal development of the small intestine of rats on the adherence of fimbriated and nonfimbriated $S$. typhimurium which is a classic pathogen for the rat (16). Isolated enterocytes from different levels of the small intestine were used as target cells. In addition, the effect of early weaning of pups and the role of rat's milk on the adherence of $S$. typhimurium were examined.

\section{MATERIALS AND METHODS}

Animals. All experiments were performed using Sprague-Dawley rats. Pups were obtained from timed-pregnant females. The day of birth was considered as day 0 . Unless otherwise stated, rats were allowed to nurse before weaning until the time when they were killed by decapitation at various ages specified below.

Enterocyte isolation. Small intestinal enterocytes were isolated as described previously (17) with slight modifications (18). Briefly, segments from the proximal intestine starting at the pylorus and from the most distal part of ileum (to the ileocecal valve) were processed simultaneously. The lengths of the segments varied with the age of the rat: $14 \mathrm{~cm}$ in the 7 day old, 21 $\mathrm{cm}$ in the 14 day old, $23 \mathrm{~cm}$ in the 16 day old, and $25 \mathrm{~cm}$ in other age groups. Each segment was excised and trimmed of fat and mesentery. The segment was split open longitudinally and 
washed twice by gentle agitation in $5 \mathrm{ml}$ of isolation buffer (see below). The segment was incubated for 2 min on a New Brunswick gyratory shaker at $400 \mathrm{rpm}$ at $37^{\circ} \mathrm{C}$. All glassware was siliconized and all incubations were carried out under $100 \%$ oxygen. The supernatant fluid was discarded and the intestinal segment was resuspended in fresh isolation buffer and incubated for another $10 \mathrm{~min}$ with shaking. This procedure was repeated twice and the supernatant fluids were collected combined and filtered through four layers of cheese cloth. The cell suspension was centrifuged for $2 \mathrm{~min}$ at $1500 \mathrm{rpm}$ and the pellet was washed twice, resuspended in enough isolation buffer to make an appropriate cell density $\left(10^{5}\right.$ to $\left.10^{6} / \mathrm{ml}\right)$ and quantitated microscopically using a hemocytometer. The isolation buffer consisted of $24.5 \mathrm{mM}$ HEPES, $98 \mathrm{mM} \mathrm{NaCl}, 6 \mathrm{mM} \mathrm{KCl}, 2 \mathrm{mM} \mathrm{KH} 2 \mathrm{PO}_{4}, 5$ $\mathrm{mM}$ sodium puruvate, $6 \mathrm{mM}$ sodium fumarate, $5 \mathrm{nM}$ sodium glutamate, $11.5 \mathrm{mM}$ glucose, $2 \mathrm{mM}$ glutamine, $0.2 \%$ (wt/vol) bovine serum albumin, $2 \%$ (vol/vol) amino acid mixture and $1 \%$ (vol/vol) essential vitamin mixture. The $\mathrm{pH}$ of the solution was adjusted to 7.4. All reagents were obtained from Sigma Chemical Company (St. Louis, MO) except the amino acid mixture (GIBCO, Grand Island, NY) and the vitamin mixture (M. A. Bioproducts, Walkersville, MD). The number of enterocytes that were isolated from the proximal and distal intestine ranged from $2 \times 10^{6}$ to $5 \times 10^{7}$, even in the 7 -day-old pups with shorter intestines. Phase contrast microscopy demonstrated that the size and morphologic appearance of enterocyte were similar in all of the ages studied. The enterocyte yield from the proximal and the distal intestine was similar. The integrity of enterocytes was determined by the Trypan blue exclusion test. More than $90 \%$ of enterocytes excluded the dye throughout the experimental period in all age groups studied.

Bacteria. S. typhimurium strains S $7471 \mathrm{~N}$, a nonfimbriated (fim-) FIRN biotype (19) and S $7471 \varnothing \mathrm{F}$ which is a transductant of S $7471 \mathrm{~N}$ and phenotypically fimbriated (fim + ) were used for the studies. Both strains were kindly provided by Dr. P. T. LoVerde of the State University of New York at Buffalo (20). Bacteria were grown in $10 \mathrm{ml}$ Luria broth at $37^{\circ} \mathrm{C}$ under aerobic and static conditions for $36 \mathrm{~h}$ to promote fimbriae formation that was documented by electron microscopy using the shadow casting technique. The presence of type 1 fimbriae was confirmed by its agglutination of rat, guinea pig, and human erythrocytes that was inhibitable by D-mannose or $\alpha$-methyl-D-mannoside (21). For adherence studies, cultures were grown statically for 36 $\mathrm{h}$ at $37^{\circ} \mathrm{C}$ in $10 \mathrm{ml}$ Luria broth containing $\left(8{ }^{3} \mathrm{H}\right)$ adenine $(10$ $\mu \mathrm{Ci} / \mathrm{ml})$. The growth was followed by measuring with a KlettSummerson colorimeter (no. 66 filter) the turbidity of the culture that was related to colony-forming units. The broth culture was centrifuged at $10,000 \times g$ for $10 \mathrm{~min}$. The pellet was washed twice in phosphate-buffered saline and finally resuspended in fresh isolation buffer. Incorporation of $\left(8-{ }^{3} \mathrm{H}\right)$ adenine was measured in a Beckman KS 1800 liquid scintillation spectrometer. The usual specific activity of the radiolabeled bacteria was approximately $1000 \mathrm{cpm} / 1-3 \times 10^{6}$ bacteria.

Adherence assay. The methodology used has been described previously (18). Briefly, a suspension of freshly prepared radiolabeled bacteria $(0.5 \mathrm{ml})$ containing $1 \times 10^{7}$ to $1 \times 10^{9}$ colonyforming units was incubated with $0.5 \mathrm{ml}$ freshly isolated enterocytes at $37^{\circ} \mathrm{C}$ for $30 \mathrm{~min}$ in a plastic tube on a slowly rotating wheel. In each experiment a ratio of 500 bacteria per enterocyte was used. Separation of enterocyte bound bacteria from free bacteria was performed by filtration through a polycarbonate membrane filter (Nucleopore, $5-\mu \mathrm{m}$ pore size). The incubation tube was rinsed twice with PBS and the washings were filtered through the membrane. The membrane was then washed four times with PBS, transferred to a scintillation vial with $5.0 \mathrm{ml}$ of scintillation fluid and counted in a scintillation spectrometer.

Milk collection. After oxytocin injection, milk was collected from different rat dams according to previously described methods (22). The milk was pooled and stored at $-20^{\circ} \mathrm{C}$ until used for the experiments described below.
Statistical methods. Adherence was expressed as the mean number of bacteria bound per enterocyte $\pm S D$. Analyses of variance was used to determine if there were difference among the various groups. Student's $t$ test was used to determine the significance of difference between the means of two different groups. A $p$ value of $<0.05$ was considered significant.

\section{RESULTS}

Adherence of $S$. typhimurium to rat enterocytes. Table 1 shows that the number of fimbriated bacteria adhered per enterocyte was significantly higher than the number of adhered nonfimbriated bacteria in all age groups $p<0.001$. Similar results were obtained with enterocytes from the proximal and distal small intestine. The number of adhered fimbriated bacteria increased significantly up to 30 days of age. In 7-day-old pups, the number of fimbriated bacteria adhered was $1.7 \pm 1.1$ per enterocyte in the proximal intestine and $2.6 \pm 1.4$ in the distal intestine. This level was three times higher in 14-day-old animals and five to six times higher in 21-day-old animals both in the proximal and the distal intestine. In adult animals, the number of fimbriated bacteria adhered was nine times higher in the proximal intestine and seven times higher in distal intestine compared to 7-day-old pups. There was no significant difference in the number of bacteria adhered to enterocytes isolated from the 30-day-old pups and the adult animals.

Effect of early weaning. Pups that were 16 days old were weaned prematurely by removing the pups from their mothers and simultaneously introducing powdered laboratory food as described previously (22). They were killed on the 19th day of age together with controls (breast-fed littermates). Enterocytes were isolated and adherence was studied under standard conditions. Table 2 shows that there was no significant difference in the number of bacteria adhered to enterocytes isolated from early weaned animals compared to controls from two separate litters of about 10 pups each.

Treatment of enterocytes or bacteria, with rat's milk. Enterocytes from adult animals or Salmonella were separately treated with rat's milk in vitro to see if there were factors in the rat milk that interfered with the adherence of $S$. typhimurium to enterocytes and which could result in an apparent lower number of

Table 1. Adherence of $S$. typhimurium to isolated small intestinal enterocytes in rats of different ages

\begin{tabular}{|c|c|c|c|c|}
\hline \multirow{3}{*}{$\begin{array}{l}\text { Age group } \\
\text { (no. expt.) }\end{array}$} & \multicolumn{4}{|c|}{ Adherence* } \\
\hline & \multicolumn{2}{|c|}{ Proximal intestine } & \multicolumn{2}{|c|}{ Distal intestine } \\
\hline & Fim $+\dagger$ & Fim-ł & Fim+ & Fim- \\
\hline $\begin{array}{l}7 \text { days } \\
(6)\end{array}$ & $1.7 \pm 1.1$ & $0.4 \pm 0.6$ & $2.6 \pm 1.4$ & $1.4 \pm 1.5$ \\
\hline $\begin{array}{l}14 \text { days } \\
(6)\end{array}$ & $4.4 \pm 2.5 \S$ & $1.0 \pm 1.5$ & $8.9 \pm 1.3 \S$ & $1.2 \pm 1.5$ \\
\hline $\begin{array}{l}16 \text { days } \\
\text { (5) }\end{array}$ & $7.9 \pm 1.7$ & $1.4 \pm 1.3$ & $9.6 \pm 4.1$ & $0.9 \pm 0.9$ \\
\hline $\begin{array}{l}21 \text { days } \\
\text { (4) }\end{array}$ & $11.1 \pm 5.2 \|$ & $5.0 \pm 5.6$ & $13.5 \pm 3.9$ & $3.7 \pm 3.9$ \\
\hline $\begin{array}{l}30 \text { days } \\
\text { (5) }\end{array}$ & $16.3 \pm 7.2$ & $2.7 \pm 0.8$ & $19.9 \pm 4.2$ & $2.5 \pm 1.8$ \\
\hline $\begin{array}{l}\text { Adult } \\
\text { (10) }\end{array}$ & $14.0 \pm 5.3$ & $4.4 \pm 3.0$ & $19.6 \pm 9.6$ & $3.5 \pm 2.8$ \\
\hline
\end{tabular}

* Mean no. of bacteria bound per enterocyte \pm SD for the number of experiments indicated. Each experiment was run with triplicate samples.

$\dagger$ Fimbriated strain, S $7471 \varnothing \mathrm{F}$.

$\ddagger$ Nonfimbriated strain, $S 7471 \mathrm{~N}$.

$\S$ Significant difference $(p<0.01)$ between 7 and 14 days.

\| Significant difference $(p<0.001)$ between 14 and 21 days. Analyses of variance showed a significant difference exist between ages $(\mathrm{F}=17.8$, $p<0.001)$ and strains $(\mathrm{F}=142.9, p<0.001)$. 
Table 2. Effect of early weaning on adherence of Salmonella typhimurium (Fim +) to isolated enterocytes from proximal small intestine of rats

\begin{tabular}{lcccc}
\hline & & \multicolumn{3}{c}{ Adherence* } \\
\cline { 3 - 5 } \multicolumn{1}{c}{ Animal } & (No. expt.) & Litter $1 \dagger$ & (No. expt.) & Litter $2 \ddagger$ \\
\hline Early weaned $\dagger$ & $(4)$ & $5.8 \pm 2.0$ & $(5)$ & $8.0 \pm 0.8$ \\
Control & $(4)$ & $8.7 \pm 5.6$ & $(5)$ & $9.1 \pm 1.6$ \\
\hline
\end{tabular}

* Mean no. of bacteria bound per enterocyte \pm SD for the number of experiments indicated. Each experiment was run in triplicate.

$\dagger$ Pups were weaned at 16 days of age by separating them from their mother and introducing them to solid foods. Pups were killed on the 19 th day of life and enterocytes were isolated. Adherence of $S$. typhimurium to enterocytes was studied under standard conditions.

$\$$ Pups were weaned at 15 days of age to allow for more time of exposure to solid food. Weaning was performed as outline above.

adhered bacteria. Table 3 shows that pretreatment of $10^{6}$ enterocytes $(1.0 \mathrm{ml})$ with $150 \mu \mathrm{l}$ rat milk for $10 \mathrm{~min}$ at $4^{\circ} \mathrm{C}$ did not affect the number of bacteria adhered. Similarly, pretreatment of bacteria with rat milk in the same ratio of volume also did not change the adherence of bacteria to the enterocytes.

\section{DISCUSSION}

The present study demonstrates that fimbriated S. typhimurium adheres to isolated rat enterocytes in significantly higher numbers than nonfimbriated counterparts in all age groups studied. These results agree with our previous study (18) and earlier studies of adherence of $S$. typhimurium to surface integuments of Schistosoma that demonstrated that type 1 fimbriae mediated the adherence (20). Golderman and Rubinstein (24) also found that mannose sensitive adhesions in Salmonella facilitated adherence to intestinal mucosa in mice.

Our study also demonstrates an age-dependent increase in binding of $S$. typhimurium to rat enterocytes. The number of adhered bacteria was low in 7-day-old pups, then increased gradually and significantly with age and reached adult levels at weaning suggesting maturational events in the enterocytes.

Marked developmental changes, e.g. physiologic processes, mucosal proteins and carbohydrates, digestive enzymes, and intestinal flora occur in the gastrointestinal tract during postnatal maturation in the rat $(25,26)$. In the first 2 wk of life, the small intestinal epithelium is immature both structurally and functionally $(25,26)$. During the $3 \mathrm{rd} \mathrm{wk}$, a rapid maturation process takes place. At 4-5 wk of age, the adult levels of enzymes and patterns of membrane biochemistry are apparent. Surface properties of small intestinal epithelial cells and microvillus membranes of rats have been studied using various lectins as probes (12). These studies indicated maturational changes in reactive surface carbohydrate terminals. It is conceivable that receptors responsible for bacterial adherence undergo similar developmental changes.

Postnatal development of the rat small intestine is characterized by increased mass, DNA, and $\alpha$-glucosidases and decreased lactase content approximately 17-21 days of age $(23,25)$. Forced early weaning of breast-fed pups with powdered laboratory food has been shown to result in precocious increase of intestinal length as well as increase of maltase and sucrase and decrease in lactase activities after only 2 days (23). This has been attributed to a change in the diet associated with weaning. However, the segmental mucosal weight, DNA, and protein contents showed parallel increases in both early weaned and control pups, suggesting preprogramed control of these parameters rather than dietary effects (23). Studies with prolonged nursing of rats also supported the hypothesis that a combination of dietary and genetic factors affect intestinal development (23). Our results on the binding of $S$. typhimurium to small intestinal cells from forced early weaned pups, however, did not show significant
Table 3. Effect of rat milk on adherence of $S$. typhimurium to enterocytes from small intestine of adult rats

\begin{tabular}{llc}
\hline & \multicolumn{2}{c}{ Adherence* } \\
\cline { 2 - 3 } (no. expt.) & $\begin{array}{l}\text { Proximal } \\
\text { intestine }\end{array}$ & $\begin{array}{c}\text { Distal } \\
\text { intestine }\end{array}$ \\
\hline $\begin{array}{c}\text { A. Pretreatment of enterocyte } \\
\text { With milk } \dagger\end{array}$ & $10.2 \pm 3.8$ & $10.8 \pm 3.6$ \\
(4) Without milk & $13.5 \pm 9.0$ & $15.5 \pm 4.7$ \\
(4) & &
\end{tabular}

B. Pretreatment of bacteria

$\begin{array}{lc}\text { With milk } \ddagger & 10.8 \pm 2.1 \\ \text { (6) Without milk } & 11.8 \pm 2.3\end{array}$

(6)

* Mean number of bacteria bound per enterocyte $\pm \mathrm{SD}$ for the number of experiments indicated. Each experiment was run in triplicate.

$\dagger 10^{6}(1 \mathrm{ml})$ of freshly prepared enterocytes from adult rat were incubated with $150 \mu \mathrm{l}$ rat milk and another sample of enterocytes from the same preparation was incubated with the isolation buffer to serve as controls (without milk) for $10 \mathrm{~min}$ on a slowly rotating wheel at $4^{\circ} \mathrm{C}$. Enterocytes were washed twice with the isolation buffer and adherence of fim $+S$. typhimurium (S $7471 \varnothing \mathrm{F}$ ) was studied under standard conditions.

$\ddagger 10^{9}(1 \mathrm{ml})$ of freshly harvested ${ }^{3} \mathrm{H}$-labeled Salmonella (fim + ) were incubated with $150 \mu \mathrm{l}$ rat milk and another sample of Salmonella from the same harvest was incubated with the isolated buffer to serve as control (without milk) for $10 \mathrm{~min}$ on a slowly rotating wheel at $4^{\circ} \mathrm{C}$. Bacteria were washed twice with the isolation buffer and adherence of the milk incubated and control Salmonella to enterocytes freshly prepared from adult rats were studied under standard conditions.

difference compared with those in small intestinal cells from control litter mates. These data suggest that the development of binding capacities to $S$. typhimurium in isolated enterocytes is inherently preprogramed and that dietary changes play an insignificant role, if any, in the acquisition of this ability.

Breast-feeding of infants has been universally documented to protect infants against gastroenteritis as well as other infections $(1,5)$. This is especially important for populations living in poor hygienic conditions with heavy microbial exposure through contaminated food and water. The level of specific immunoglobulins in breast milk is an important protective factor. For example, breast milk with specific IgA antibodies against Vibrio cholera lipopolysaccharide and enterotoxin was shown to have protective effects against cholera (27). However, breast-feeding does not seem to prevent intestinal colonization with $E$. coli $(28)$ or $V$. cholera (27). Rat milk contains IgA and IgG, but not IgM from the first day of lactation (29). As yet, their specific effects in protection against Salmonella infection have not been evaluated. Nonspecific factors, such as lactoferrins, lysozyme, and lactoperoxidase in breast milk are also considered to be protective against infections (5). Receptors analogous to those in epithelial cells for certain bacteria such as Pneumococci and Haemophilus influenzae $(5,30)$ have been demonstrated in human milk and suggested to have protective functions. The present study demonstrated that pretreatment of enterocytes or Salmonella in vitro with rat's milk did not significantly change the level of adherent bacteria to adult enterocytes. This indicates an absence or ineffectiveness of factors in rat's milk which interferes with the binding of $S$. typhimurium to adult enterocytes under the experimental conditions. It is therefore unlikely that such factors would prevent the adherence of $S$. typhimurium to enterocytes of newborn pups in vitro, and that the lower numbers of bacteria adhered to enterocytes in the neonatal period could be accounted for by the consumption of milk. Animal studies have suggested developmental changes of adherence levels to intestinal mucosa 
or isolated intestinal cells for various strains of $E$. coli and Shigella flexneri $(6,13,15)$. Thus, $E$. coli (RDEC-1), a rabbit enteropathogenic bacterium did not adhere to rabbit intestinal brush border membranes before 21 days of age. The adherence then increased and eventually reached adult levels at 35 days of age (6). Studies of adherence of E. coli $0111 / \mathrm{B} 4$ to the mucosa of closed intestinal loops of rabbits and rats showed higher adherence levels to the intestines of immature compared with those from adult animals (15). However, studies of the adherence of enterotoxinogenic $E$. coli 0128 to guinea pig small intestinal cells did not show any differences in animals of various ages (13). However, using the same model system, the adherence to colonic cells was found to be low in the newborn, but reached adult values at 1 wk of age (13). Inasmuch as the adherence of E. coli 0128 is considered to be mediated by mannose-containing receptors available on the ileal surface in guinea pigs both in newborn and adult animals, these results contrasted with the agedependent occurrence of mannose-specific small intestinal receptors demonstrated for $E$. coli $0111 / \mathrm{B} 4$ in rabbits and rats (15). Our study suggests that the availability of mannose-specific receptors for $S$. typhimurium is gradually developed or unmasked during postnatal maturation of small intestinal enterocytes in the rat.

Although the significance of these animal data in terms of human disease is not known at present, adherence to epithelial cells is recognized to be a prerequisite for many pathogenic bacteria to cause acute infection in humans $(9,10)$. Recently it has been shown in human studies that adherence alone may result in damage to the intestinal epithelium, e.g. enteroadherent $E$. coli was associated with ultrastructural changes in microvillus membranes of small intestinal cells (31). Reports have also emphasized adherence to intestinal mucosa by certain strains of $E$. coli as one factor in the pathogenesis of protracted diarrhea in infancy (31). Human studies have also indicated that bacterial binding sites on epithelial cells are not available immediately after birth but can be demonstrated after a few days. Thus, lower numbers of Streptococci adhered to oral mucosal cells (33) and Staphylococci to nasal mucosa (34) in infants during the first $48 \mathrm{~h}$ of life than in adults.

The present study has indicated that the number of available binding sites for $S$. typhimurium on isolated small intestinal rat enterocytes increases with age and is apparently preprogrammed. Age-dependent differences in affinity of enterocytes and other epithelial cells for bacteria have important implications for both pathobiology and pathophysiology. Such changes in enterocyte properties may contribute to the developmental characteristics of the normal intestinal colonization as well as to the agedependent clinical pattern of bacterial intestinal infections.

\section{REFERENCES}

1. Harries JT 1976 The problem of bacterial diarrhoea. In: Acute Diarrhoea in Childhood. Ciba Foundation Symposium 42. Elsevier, New York, pp 3-16

2. Tzipori $S$ (ed) 1985 Infectious Diarrhea in the Young. Strategies for Contro in Humans and Animals. Elsevier Sci Publ B.V. (Biomedical Division), Amsterdam

3. Vesikari T, Maki M, Sarkkinen HK, Arstila PP, Halonen PE 1981 Rotavirus, adenovirus and non-viral enteropathogens in diarrhoeas. Arch Dis Child 56:264-270

4. WHO Scientific Working Group 1980 Enteric infections due to Campylobacter, Yersinia, Salmonella, and Shigella. Bull WHO 58:519-537

5. Hanson LA, Hofvander Y, Lindquist B, Zetterstrom R 1985 Breast-feeding as a protection against gastroenteritis and other infections. Acta Paediatr Scand 74:641-642

6. Cheny CP, Boedeker EC 1984 Rabbit mucosal receptors for an enteropathogenic Escherichia coli strain: appearance of bacterial receptor activity at weaning. Gastroenterology 87:821-826
7. Cheney CP, Schad PA, Formal SB, Boedeker EC 1980 Species specificity of in vitro $E$. coli adherence to host intestinal cell membranes and its correlation with in vivo colonization and infectivity. Infect Immun 28:1019-1027

8. Formal SB, Hale TL, Sansonette 1983 Invasive enteric pathogens. Rev Infect Dis 5:S702-S707

9. Freter R 1981 Mechanisms of association of bacteria with mucosal surfaces In: Adhesion and Microorganism Pathogenicity. Ciba Foundation Symposium 80 . Pitman Medical, Tunbridge Wells pp 36-55

10. Ofek I, Beachey EH 1980 General concepts and principles of bacterial adherence in animal and man. In: Beachy EH (ed) Bacterial adherence. Receptors and Recognition. Series B, Vol 6. Chapman and Hall, London, pp 2-29

11. Ofek I, Beachey EH, Sharon N 1978 Surface sugars of animal cells as determinants of recognition in bacterial adherence. Trends Biochem Sci 3:159160

12. Mahmmod A, Torres-Pinedo R 1983 Postnatal changes in lectin binding to microvillus membrane from rat intestine. Biochem Biophys Res Commun 2:400-406

13. Ashkenazi S, Mirelman D 1984 The effect of postnatal age on the adherence of Shigella flexneri, Escherichia coli 0124 , and E. coli 0128 to guinea pig intestinal cells. Pediatr Res 18:1366-1371

14. Ashkenazi S, Cinari G, Mirelman D 1986 The ontogeny of bacterial adherence to the gut. Animal studies and their relation to infantile intestinal disease. Front Gastrointest Res 13:84-292

15. Thaler MM, Hirschberger M, Mirelman D 1977 Adherence of $E$. coli to immature intestine is mediated by mucosal receptors of mannose-specific lectins. Clin Res 25:469A(abstr)

16. Weisbroth SH 1979 Bacterial and mucotic diseases. In: Baker HJ, Lindsey JR Weisbroth SH (eds) The Laboratory Rat, Vol I. Academic Press, New York, pp 218-241

17. Toyoda S, Lee PC Lebenthal E 1985 Physiological factors controlling release of enterokinase from rat enterocytes. Dig Dis Sci 30:1174-1180

18. Lindquist BL, Lebenthal E, Lee PC, Stinson MW, Merrick JM 1987 Adherence of Salmonella typhimurium to small intestinal enterocytes of the rat. Infect Immun 55:3044-3050

19. Dugoid JP, Anderson ES, Alfredson GA, Barker R, Old DC 1975 A new biotyping scheme for Salmonella typhimurium and its phylogenetic significance. J Med Microbiol 8:149-166

20. Mehlam RF, LoVerde PT 1984 Mechanisms of interaction of Salmonella and Schistosoma species. Infect Immun 44:274-281

21. Dugoid JP, Anderson ES, Campbell I 1966 Fimbriae and adhesive properties in Salmonellae. J Pathol Bacteriol 92:107-138

22. Michalek SM, McGee JR, Ghanta VK 1974 Complement levels in malnourished animals: measurement of complement in rat milk during the period of lactation. J Reticuloendothel Soc 16:213-219

23. Lee PC, Lebenthal E 1983 Early weaning and precocious development of small intestine in rats: Genetic, dietary or hormonal control. Pediatr Res 17:645650

24. Golderman L, Rubinstein E 1982 Salmonella and Shigella adherence to the intestine of mice. Israel J Med Sci 18:1032-1036

25. Buts JP, DeMeyer R 1981 Postnatal proximodistal development of the small bowel mucosal mass in growing rats. Biol Neonate 40:62-69

26. Lebenthal E, Lee PC, Heitlinger LA 1983 Impact of development of the gastrointestinal tract on infant feeding. J Pediatr 102:1-9

27. Glass RE, Svennerholm AM, Stoll BJ, Khan MR, Hossain KMB, Huq MI Holmgren J 1983 Protection against cholera in breast-fed children by antibodies in breast milk. N Engl J Med 308:1389-1392

28. Carlsson B, Kaijser B, Ahlstedt S, Gothefors L, Hanson LA 1982 Antibodies against Escherichia coli capsular $(\mathrm{K})$ antigens in human milk and serum. Their relation to the $E$. coli gut flora of the mother and the neonate. Acta Paediatr Scand 71:313-318

29. Michalek SM, Rahman AFR, McGhee JR 1975 Rat immunoglobulins in serum: comparison of IgM, IgA and IgG in serum, colostrum, milk and saliva of protein malnourished and normal rats. Proc Soc Exp Biol Med 148:1114-1118

30. Hanson LA, Ahlstedt S, Anderson B, Carlsson B, Cole MF, Cruz, JR, Dahlgren U, Ericsson TH, Jalil F, Khan SR, Mellander L, Schneerson R, SvanboryEden C, Soderstrom T, Wadsworth C 1983 Keynote address: mucosal immunity. Ann NY Acad Sci 409:1-21

31. Ulshen MH, Rollo JL 1980 Pathogenesis of E. coli gastroenteritis in mananother mechanism. N Engl J Med 302:99-101

32. Rothbaum R, McAdams AJ, Gianella R, Partin JC 1982 A clinicopathological study of enterocyte-adherent $E$. coli, a cause of protracted diarrhea in infants. Gastroenterology 83:441-454

33. Ofek I, Beachey EH, Eyal F, Morrison JC 1977 Postnatal development of binding of Streptococci and lipoteichoic acid by oral mucosal cells of humans. J Infect Dis 135:267-274

34. Aly R, Colman J, Shinefield H, Maibach E, Strauss W 1978 Comparison of Staphylococcus adherence to nasal mucosa of infants and adults. Clin Res 26:389A(abstr) 